\title{
Kentsel Donatı Elemanlarının Peyzaj Mimarlığı Açısından Değerlendirilmesi: Çankırı Örneği
}

\author{
Nazan KUTER ${ }^{1 *}$, Zeynep KAYA ${ }^{2}$ \\ ${ }^{1}$ Çankırı Karatekin Üniversitesi, Orman Fakültesi, Peyzaj Mimarlığı Bölümü, 18200, ÇANKIRI \\ ${ }^{2}$ Çankırı Karatekin Üniversitesi, Fen Bilimleri Enstitüsü, Peyzaj Mimarlığı Anabilim Dalı, 18200, ÇANKIRI
}

Öz

Sokak, cadde, meydanlar ve rekreasyon amaçlı tasarlanmış genel ya da özel kullanım alanlarında yer verilen kentsel donatı elemanları, kentsel yaşam kalitesinin artırılmasına katkı sağlayan önemli peyzaj elemanlarıdır. Bulundukları çevre ile bütünleşerek kentin önemli bir öğesi haline gelen kentsel donatı elemanları, kent ile kurdukları bütünlük ile bir kentin kimliğinin oluşmasına katkı sağlayan en önemli araçlardan biridir. $\mathrm{Bu}$ araştırmanın temel amacı, kentsel donatı elemanlarının sınıflandırılarak, peyzaj mimarlığı açısından değerlendirilmesidir. Bu amaca yönelik olarak, merkezi konumları ve yoğun kullanıma sahip olmaları nedeni ile Çankırı kent merkezinde yer alan Alparslan Türkeş Caddesi ve Necip Fazıl Kısakürek Sokağı araştırma alanı olarak seçilmiştir. İlk olarak; kentsel donatı elemanlarının tanımı yapılarak, önemi, tasarım ilkeleri, özellikleri, kullanım türleri belirtilmiş ve işlevlerine göre sınıflandırmaları verilmiştir. Devamında; seçilen araştırma alanlarında yer alan kentsel donatı elemanları bu teorik yaklaşımlar doğrultusunda sınıflandırılarak değerlendirilmiştir. Son aşamada ise, araştırma alanlarındaki kentsel donatı elemanları peyzaj mimarlı̆̆ı meslek disiplini açısından irdelenmiş ve özgün kentsel mekânlar oluşturulması kapsamında öneriler getirilmiştir.

Anahtar Kelimeler: Peyzaj tasarımı, kentsel estetik, kent mobilyaları.

\section{Evaluation of Urban Furniture from the aspect of Landscape Architecture: Case of Çankiri}

\begin{abstract}
Urban furniture, designed to be used in streets, avenues, squares and recreational areas for general or private use, are important landscape elements that contribute to increase the quality of urban life. Urban furniture are considered as one of the most significant tools that contribute to the formation of a city with the integrity that they establish with the city. The main scope of this research is the classification and assessment of urban furniture within the frame of landscape architecture. For this purpose, Alparslan Türkeş Avenue and Necip Fazıl Kısakürek Street, which are located in Çankırı city center, were chosen as the research area because of their central location and intensive use. Firstly, the definition of urban furniture was introduced and their importance, design principles, characteristics and types of use were indicated, and their classifications according to their functionality were given. Subsequently; the urban furniture in the research areas were classified and evaluated according to above mentioned theoretical approaches. In the last stage; urban furniture in the fields of research were assessed in terms of landscape architecture discipline and suggestions were made within the scope of creating original urban spaces.
\end{abstract}

Keywords: Landscape design, urban aesthetics, urban furniture. 


\section{Giriş}

Sosyo-kültürel, fiziksel ve psikolojik ihtiyaçların karşılanmasında önemli işlevsel niteliğe sahip olan kentler, toplumların kültürlerini, yaşam kalitelerini, yaşam biçimlerini ve tarihi değerlerini yansıtan mekânlardır (Kuter ve Erdoğan, 2009). Yaşanılan çevrede konforun ve çevre kalitesinin göstergesi durumundaki; oturma, barınma, korunma, kuşatma, ulaşım, aydınlatma, iletişim, oyun, spor vb. gibi temel fonksiyonları destekleyip güçlendiren, toplumsal yaşamı kolaylaştırıp bireyler arası iletişimi sağlayan, mekâna işlevsel ve estetik açıdan belirli bir anlam kazandıran, değişik nitelik ve niceliklerde olan, mekânı tanımlayan ve tamamlayan, kullanıcıların beğenilerini kazanan peyzaj elemanları "kentsel donatı elemanları" olarak adlandırılmaktadırlar (Sağlık ve ark., 2014). Kentlere kimlik kazandıran kentsel donatı elamanları, ortak kullanıma yönelik çevreyi tanımlayan, belirleyici, yönlendirici ve bilgilendirici niteliğe sahip olan, alt yapıyla ilişkili, işlevsel ve görsel amaca uygun elemanlardır.

Kentsel donatı elemanlarının geçmişten bugüne kadar gelişimi irdelendiğinde; seri üretim endüstrisinin Anadolu'da çok eski dönemlere kadar dayandığ 1 görülmektedir. Türkiye'de 1980 yılından itibaren endüstri tasarımcıları, peyzaj mimarları, mimarlar ve çevre bilimcileri tarafindan kullanılan kentsel donatı elemanları yerine "kent mobilyaları", "çevre donatı elemanları", "kent aksesuarları", "çevre düzenleme öğeleri” gibi terimler de kullanılmaktadır. Kentsel tasarım ya da peyzaj tasarım çalışmalarında, insanların bilgi, güvenlik ve konforuna yönelik fiziksel gereksinimlerini karşılayan, çevre temizliği ve sağlığ olabilecek farklı yapısal elemanlara ihtiyaç duyulmaktadır. Kentsel donatı elemanı olarak adlandırılan bu yapısal elemanlar, doğru kullanıldıkları zaman peyzaj tasarımının görsel kalitesini arttırarak kullanıcılara biçim, renk, doku, malzeme özellikleri dâhilinde belirli bir algı oluşturmaktadırlar (Kuter ve Erdoğan, 2009). Ortak yaşam alanı olan ve toplumun yaşam biçimleri, kültürleri ile tarihi değerlerini yansıtan mekânlar olarak planlanan kentleri yaşanabilir ve algılanabilir kılan kentsel donatı elemanlarının her biri hem kullanıcılar hem de kent açısından farklı anlam ve öneme sahiptirler. Kullanıcılar açısından önemli olan kentsel donatı elemanlarında görsel ve fiziksel ilişki önemlidir. Kent açısından ise kentsel donatı elemanları bulundukları çevreyi tanımlayan, belirleyen ve özelleştiren nitelikleri nedeniyle önem taşımaktadırlar.

Kentsel mekânlarda yer alan kentsel donatı elemanlarının her biri birer kullanım ve iletişim nesnesi olarak değerlendirilmektedirler. Aynı zamanda birer görsel obje olarak da tanımlanan kentsel donatı elemanları, kent kimliğinin bir parçası olarak nitelendirilmekte; özel bir tasarım ürünü olma özellikleri ve yer aldıkları kentsel mekân ile ilişkileri ile ele alınmaktadırlar (Bayraktar ve ark., 2008). Kente görsel zenginlik ve kimlik kazandıran ve üç boyutlu öğeler olan kentsel donatı elemanları, kentte sınırlandırıcı olan duvar, çit vb. gibi elemanlar ile vurgulayıcı olan lamba, bank, tabela, heykel vb. gibi elemanlar olarak mekânı güçlü hissettirerek zengin bir kent görünümünün sağlanmasına yardımcı olmaktadırlar (Taylor, 1999). Donatı elemanları insanaraç-çevre sisteminin bir parçası olarak aynı zamanda birer kültür öğesi olarak da kabul edilmektedirler. Bir yandan her donatı elemanı yapılı çevrenin bir parçası olarak bulunduğu yeri tanımlayan bir özelliğe, kullanıcılar için görsel bir obje niteliğine ve kent için sembolik bir anlama sahiptir. Bu nedenle kentsel tasarım ve kentsel peyzaj tasarımında önemli bir rol oynayan kentsel donatı elemanlarının tasarımı, üretimi ve mekân içindeki konumunun planlama-tasarım sürecinden soyutlanamayacağı gerçeği göz ardı edilmemeli, bir araya getirilişlerinde ise bir bütün olmalarına özen gösterilmelidir. Kentsel donatı elemanlarının işlevsel benzerlikleri nedeniyle ortak bir dil özelliği taşımaları ile bir bütün oluşturmaları beklenmektedir. Bu ortak dil nedeni ile donatı elemanları kent içindeki sürekliliğin ve bütünlüğün birer parçası, kenti yaşanabilir ve algılanabilir kılan birer kimlik öğesi olarak değerlendirilmelidirler (Aydoğdu, 2017). Kent yaşamını kolaylaştıran, kent konforunu sağlayan ve kent imajına büyük katkı sağlayan kentsel donatı elamanlarının estetik ve işlevsel olabilmeleri için tasarımlarının yapılmasında bilimsel verilerin dikkate alınması son derece önem taşımaktadır. Kentsel donatı elemanlarının birer tasarım ürünü olarak ele alınmalarını sağlayacak, birbirleri ve yer aldıkları kentsel mekânlar ile doğru ilişkiler kurmalarını olanaklı kılacak bazı yaklaşımlara gereksinim duyulmaktadır. Tasarım ilkeleri dikkate alınarak yapılan kentsel donatı elemanları, kullanıcılar tarafindan hem daha çok beğenilmekte ve daha işlevsel olarak kullanılabilmekte hem de kullanıcıların onları daha bilinçli kullanmalarını sağlamaktadır. Kentsel donatı elamanlarının tasarım süreçlerinde; tasarım ilkeleri ile ulusal/uluslararası standartların dikkate alınmasının yanı sıra kentsel mekânın kültürel özellikleri ile uyumlu olmasına, evrensel olduğu için herkese hitap etmesine ve kullanıcıların gereksinimlerinin dikkate alınmasına ihtiyaç duyulmaktadır. Kamu kurum ve kuruluşlarının sorumluluğu altında olan kentsel donatı elemanları tasarlanırken ölçek, renk, doku, malzeme, form vb. gibi tasarım ögelerinin dikkate alınması, kullanıcıların onları daha rahat algılamalarına da yardımcı olmaktadır.

Kentsel donatı elemanları; sosyal, doğal ve teknik bilimler kapsamında yorumlanıp, kentsel tasarım ilkeleri doğrultusunda ergonomik olarak tasarlanmalıdırlar. Kentsel donatı elemanlarının tasarım ölçütleri; işlevsel, psikolojik ve teknolojik olmak üzere üçe ayrılmaktadır (Öner Bilen, 2004): 
- İşlevsel ölçütler: Herhangi bir nesne ve insan ilişsisinin belirlenmesine yönelik ölçütlerdir. İnsanın fiziksel ve hareket özellikleri, tüm kentsel donatı elemanlarının tasarımı için birincil tasarım ölçütüdür. $\mathrm{Bu}$ nedenle tasarımcıların, ürünü tasarlarken dikkat etmeleri gereken en önemli nokta ürünün ergonomik olmasıdır.

- Psikolojik ölçütler: Algılama ve değerlendirmeye yönelik ölçütler olup, genel olarak bireye, bireylerin oluşturduğu topluma ve toplumun sosyo-kültürel özelliklerine uygun çevre oluşumunu sağlayıcı ölçütlerdir.

- Teknolojik ölçütler: Malzeme, üretim ve ekonomiye yönelik ölçütlerdir. Tasarımın gerçekleşmesinde belirleyicidir.

Kentsel donatı elemanları tasarlanırken kullanıcıların farklı gereksinimlerinin ötesinde toplumun kültürel, sosyal ve ideolojik yapısının da dikkate alınması gerekmektedir (Siu, 2005). Yol kenarları ve yaya yolları, meydanlar ve dinlenme alanları, binalar ve çevreleri, parklar/bahçeler, kıyılar, plajlar vb. gibi kent içinde farklı mekânlarda yer alan kentsel donatı elemanları endüstriyel bir ürün olarak; kullanım amacina ve kullanıcının fiziksel özelliklerine uygun olmalı, kullanım sürecinde kullanıcıya zarar vermemelidir. Kentsel donatı elemanlarının tasarım süreçlerinde anlatım sadeliği son derece önem taşımaktadır. Tasarım sürecinde gelecekteki ihtiyaçlar göz önüne alınmalı ve buna ilişkin olanaklar irdelenmelidir. Kent mekânlarını özgün kılan, işlevsel özellik kazandıran, kullanıcıların gereksinimlerine cevap vererek bu mekânları kullanılır kılan kentsel donatı elemanları serbest ve ritmik bir düzen içinde tasarlanmalı, birbirleri ile ve yapılı çevre ile bir bağ kurmalıdır. Donatı elemanları mekânı tamamlayan özgün niteliğe sahip olmalı ve tasarımlarında malzeme ve renk seçimlerinin bütüne katkısı önemsenmelidir (Bayraktar ve ark., 2008). Kentsel donatı elemanları kentsel mekânın yerine, büyüklüğüne ve anlamına uyumlu olmalı, yer aldığı çevrenin karakterini yansıtmalı, ayrıca kullanıcılara psikolojik rahatlık sağlamaları açısından da ele alınmalı, kullanıcıların farklı gereksinimlerinin ötesinde toplumun sosyo-kültürel ve ideolojik yapısı da düşünülerek tasarlanmalıdırlar (Aydoğdu, 2017). Kentsel yaşamı kolaylaştırmaya ve daha estetik çevreler elde etmeye olanak sağlayan kentsel donatı elemanlarında bulunması gereken diğer özellikler ise (Başal ve ark., 1993; Güney ve ark., 1996; Başal ve ark., 1997; Şişman ve Yetim, 2004; Özgeriş, 2018; Kuter ve Erdoğan, 2009);

- ergonomi ve fiziksel özellikleri açısından standartlara uygun olmalı,

- tasarımlarında fonksiyonel ve estetik özellikleri dikkate alan özgün tasarımlar olmalı,

- taşınabilir ve monte edilebilir olmalı, yedek parçaları kolay bulunabilmeli,

- bakımları kolay olmalı,

- sağlam olmalı,

- vandalizm'e karşı dayanıklı olmalı şeklinde değerlendirilebilir.

Kentsel donatı elemanları kullanım türleri ve fiziksel karşılıkları bakımından dört ana grupta incelenmektedirler (Asatekin, 2001; Bayraktar ve ark., 2008; Kuter ve Erdoğan, 2009):

- Geçici kullanım amaçlı kentsel donatı elemanları: Kentlinin bir an geçerken dış mekânda bir alanı kullanıyor olmasıdır. Ulaşım etkinlikleri bu tür kullanıma girmektedir.

- Süreli kullanım amaçlı kentsel donatı elemanları: Kentlinin dış mekânda belirli bir noktayı belirli sürelerde kullanıyor olmasıdır. Bu tür kullanımlar genellikle alış-veriş yapmak, oturmak, dinlenmek, beklemeye yönelik etkinliklerdir.

- İşlevsel kullanım amaçıı kentsel donatı elemanları: Kentlinin dış mekânı kullanırken gereksinimlerine karşı işlevlere dönük kullanımlardır. Buna göre kentte yaşayan insanların iletişimsel gereksinimlerinden ve fizyolojik gereksinimlerden söz etmek olasıdır.

- Yan kullanım amaçı kentsel donatı elemanları: İncelenen üç tür kullanımının gerçekleşmesi sürecinde oluşan etkinliklere hizmet verecek kullanımlar olup, bunların düzenleme hizmetleri, bakım hizmetleri, güvenlik hizmetleri gibi alt başlıkları olabileceği gibi çevresel estetiğe dönük tinsel karşılıkları da olabilmekledir.

Birçok işlevi olan kentsel donatı elemanları farklı şekillerde sınıflandırılabilmektedir. Kentsel donatı elemanları işlevlerine göre (Bulut ve ark., 2009; Kuter ve Erdoğan, 2009);

- Zemin kaplamaları (beton, taş, ahşap, asfalt, tuğla, vb.)

- Oturma birimleri (banklar, sandalyeler, grup oturma elemanları)

- Aydınlatma elemanları (yol aydınlatıcıları, alan aydınlatıcıları)

- İşaret ve bilgi levhaları (yönlendiriciler, yer belirleyiciler, bilgi iletişim panoları)

- Sinırlandirıcilar (caydırıcilar, sınırlayıcılar, yaya bariyerleri, trafik bariyerleri, vb.)

- Su elemanları (süs havuzları, çeşmeler, tulumbalar, kanallar, yangın musluğu, vb.)

- Üst örtü elemanları (duraklar, gölgelikler, pergolalar)

- Satış birimleri (kiosklar, sergi pavyonları, büfeler, vb.)

- Sanatsal objeler (heykeller) 
- Diğer elemanlar (bayrak direkleri, çöp kutuları, posta kutuları, umumi tuvaletler, çiçeklikler, bilet otomatları, bisiklet park yerleri, parkmetreler, bitkisel ögeler) olarak sınıflandırılmaktadırlar.

\section{Materyal ve Metot}

\subsection{Materyal}

Çankırı, İç Anadolu ile Batı Karadeniz Bölgesi geçiş alanında bulunan bir yerleşim olup, güneyde Ankara ve Kırıkkale, batıda Bolu, kuzeybatıda Karabük, kuzeyde Kastamonu ve doğuda Çorum illeri ile sınırlanmıştır (Kuter, 2007). Araştırmanın ana materyalini Çankırı kent merkezinde bulunan Alpaslan Türkeş Caddesi ve Necip Fazıl Kısakürek Sokağı ile bu mekânlarda yer alan "kentsel donatı elemanları" oluşturmaktadır (Şekil 1). Araştırma alanlarına yönelik her türlü yazılı ve görsel materyal araştırma kapsamında değerlendirilmiştir.

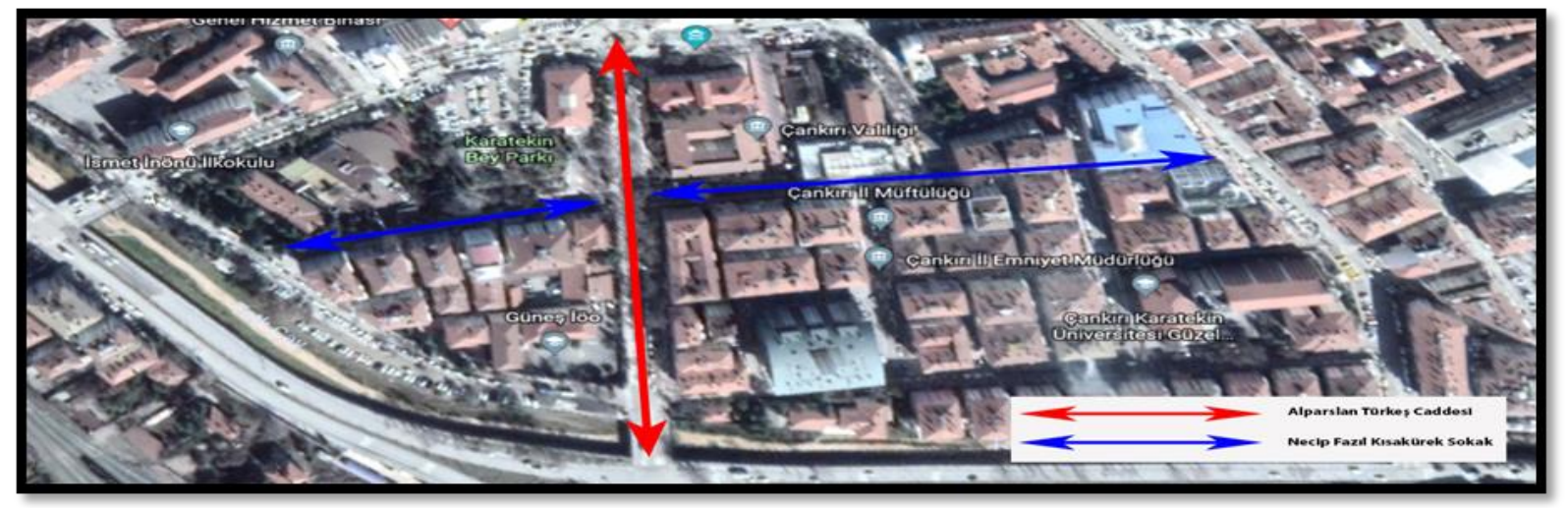

Şekil 1. Araştırma alanlarının konumu

\subsection{Metot}

Araştırmada; etüt, veri toplama, analiz ve senteze dayalı peyzaj araştırmaları yöntemi kullanılmıştır (Bulut ve ark., 2008; Özgeriş, 2018). İlk aşamada; konu ile ilgili literatür taraması yapılmış ve araştırma alanlarında bulunan mevcut kentsel donatı elamanları tespit edilerek fotoğrafları çekilmiştir. İkinci aşamada; konu ile ilgili önceki çalışmalarda yapılan sınıflandırmalardan yararlanılarak, araştırma alanlarında kullanılan "kentsel donatı elemanları” işlevlerine ve kullanım türlerine göre kendi aralarında gruplandırılmış ve tipleri belirlenmiştir. Son aşamada ise; araştırma alanlarında bulunan kentsel donatı elemanları peyzaj mimarlığı meslek disiplini açısından irdelenerek daha nitelikli çevre oluşumu kapsamında öneriler getirilmiştir.

\section{Bulgular ve Tartışma}

Çankırı kent merkezinde yer alan Alparslan Türkeş Caddesi ve Necip Fazıl Kısakürek Sokağı üzerinde bulunan kentsel donatı elemanları işlevlerine ve kullanım türlerine göre sınıflandırılmış, mevcut kentsel donatı elemanlarının tipleri ortaya konulmuş ve Tablo 1'de verilmiştir.

- Zemin Kaplamaları: Bir kentin kimliğini belirlemede önemli bir özellik olan zemin kaplamaları, peyzaj tasarım çalışmalarının temel öğesi olup üç boyutlu mekânın zeminini oluşturmaktadırlar. Buradaki belirleyici özellik, yapılan tasarımın mekânla/kentle uyumunun yanı sıra, onunla bütünlük sağlamasıdır. Doku, renk, çizgi, form özellikleri dikkate alınarak peyzaj tasarım çalışmalarında kullanılan zemin kaplamalarının seçimini etkileyen unsurların başında, zemin kaplaması yapılacak alanın işlevi, trafik, maliyet, iklim, güvenlik, dayanıklılık ve yerel koşullar gelmektedir (Başal ve ark., 1997; Güzel ve Sözen, 2003). Zemin kaplamalarının ilk işlevi, sert, kuru, kaygan olmayan bir yüzey yaratarak üzerinde yaya ve araç trafiğini taşımaktır. Yanı sıra düzgün yüzeyli zemin kaplamaları, insanı bir yöne yönelterek, onun gideceği nokta ile bulunduğu yer arasında bir bağlantı kurmasına yardım etmektedirler. Zemin kaplamalarındaki değişme ya da farklılıklar, yaya ve araç trafiği için uyarıcı etki göstererek kişi ya da sürücüyü uyarmakta, trafik hızını etkilemekte, ayrıca kişiye seviye değişimlerini (basamak ve rampaları) ve içinde bulunduğu döşemedeki kullanış değişimlerini hatırlatmaktadırlar (Yörük ve ark., 2006). Zemini oluşturan kaplamalar; kaymayı önleyici, parlamayan ve yürümeye elverişli bir dokuda olmasının yanı sıra estetik açısından da alanı tamamlayıcı özellikte olmalıdırlar. 
Tablo 1. Alpaslan Türkeş Caddesi ve Necip Fazıl Kısakürek Sokağı'nda bulunan kentsel donatı elemanlarının sınıflandırılması

\begin{tabular}{|c|c|c|c|}
\hline \multirow{2}{*}{$\begin{array}{l}\text { İşlevlerine Göre } \\
\text { Kentsel Donatı } \\
\text { Elemanları }\end{array}$} & \multirow{2}{*}{$\begin{array}{c}\text { Kullanım Türlerine } \\
\text { Göre Kentsel Donatı } \\
\text { Elemanları }\end{array}$} & \multicolumn{2}{|c|}{ Kentsel Donatı Elemanlarının Tipleri } \\
\hline & & $\begin{array}{l}\text { Alpaslan Türkeş } \\
\text { Caddesi }\end{array}$ & $\begin{array}{l}\text { Necip Fazıl } \\
\text { Kısakürek } \\
\text { Sokağı }\end{array}$ \\
\hline $\begin{array}{c}\text { Zemin } \\
\text { Kaplamaları }\end{array}$ & Geçici Kullanım & $\begin{array}{l}\text { *Araç Yolları } \\
\text { - asfalt } \\
\text { *Yaya Geçitleri } \\
\text { - waschbeton } \\
\text { *Kaldırımlar } \\
\text { - beton plak taş } \\
\text { *Bordürler } \\
\text { - beton }\end{array}$ & $\begin{array}{l}\text { *Araç Yolları } \\
\text { - asfalt } \\
\text { *Yaya Geçitleri } \\
\text { - waschbeton } \\
\text { *Kaldırımlar } \\
\text { - beton plak taş } \\
\text { *Bordürler } \\
\text { - beton }\end{array}$ \\
\hline $\begin{array}{l}\text { Aydınlatma } \\
\text { Elemanları }\end{array}$ & Yan Kullanım & $\begin{array}{l}\text { *Cadde Aydınlatması (tekli } \\
\text { *Cadde Aydınlatması (beşli } \\
\text { *Ağaç Aydınlatması }\end{array}$ & $\begin{array}{l}\text { *Sokak Aydınlatması } \\
\text { (tekli) } \\
\text { * Sokak } \\
\text { Aydınlatması (ikili) } \\
\text { *Ağaç Aydınlatması }\end{array}$ \\
\hline $\begin{array}{l}\text { İşaret ve Bilgi } \\
\text { Levhaları }\end{array}$ & İşlevsel Kullanım & $\begin{array}{l}\text { *Yönlendirme Levhaları } \\
\text {-sokak ve cadde ismi } \\
\text {-yön levhası/yer belirleyici } \\
\text {-trafik lambası } \\
\text {-trafik işareti } \\
\text { *Reklam Panoları }\end{array}$ & $\begin{array}{l}\text { Yönlendirme } \\
\text { Levhaları } \\
\text {-sokak ve cadde ismi } \\
\text {-yön levhası/yer } \\
\text { belirleyici } \\
\text {-trafik işareti } \\
\text { *Reklam Panoları }\end{array}$ \\
\hline Sinır Elemanları & Geçici Kullanım & *Bariyerler & $\begin{array}{l}\text { *Bariyerler } \\
\text { *Bitki Kasaları }\end{array}$ \\
\hline Su Elemanları & Yan Kullanım & - & $\begin{array}{l}\text { *Havuzlar } \\
\text {-Dikdörtgen formlu } \\
\text {-Dairesel formlu }\end{array}$ \\
\hline Satış Birimleri & Sürekli Kullanım & - & *Büfe \\
\hline Çöp Kutuları & Yan Kullanım & *Çöp Kutuları & $\begin{array}{l}\text { *Çöp Kutuları } \\
\text { *Çöp Konteyneri }\end{array}$ \\
\hline $\begin{array}{c}\text { İletişim İşlevine } \\
\text { Yönelik Elemanlar }\end{array}$ & İşlevsel kullanım & $\begin{array}{l}\text { *Telefon Kulübeleri } \\
\text { *Bankamatikler (ATM) }\end{array}$ & $\begin{array}{l}\text { *Bankamatikler } \\
\text { (ATM) }\end{array}$ \\
\hline $\begin{array}{l}\text { Alt Yapı Tesisleri } \\
\text { Bakım Kapakları }\end{array}$ & Yan Kullanım & *Metal Rögarlar & *Metal Rögarlar \\
\hline Yol Izgaraları & Yan Kullanım & *Metal Izgaralar & *Metal Izgaralar \\
\hline Trafolar & İşlevsel Kullanım & *Trafolar & *Trafolar \\
\hline Bitkisel Elemanlar & Yan Kullanım & $\begin{array}{l}\text { *Bitki Kasaları } \\
\text { *Yol Ağaçlandırmaları }\end{array}$ & $\begin{array}{l}\text { *Bitki Kasaları } \\
* \text { Yol } \\
\text { Ağaçlandırmaları }\end{array}$ \\
\hline
\end{tabular}

$\checkmark$ Alpaslan Türkeș Caddesi üzerinde yer alan zemin kaplamaları: Alpaslan Türkeş Caddesi üzerinde yer alan zemin kaplamaları kapsamında yapılan sınıflamaya göre; araç yollarında asfalt (Şekil 2a), yaya geçitlerinde waschbeton (Şekil 2b), kaldırımlarda beton plak taş (Şekil 2c), bordürlerde ise beton (Şekil 2d) kullanıldığ tespit edilmiştir. Özellikle kaldırımlarda bulunan zemin kaplamaları, gerek yapım aşamasındaki hatalar, gerekse yapım sonrası bakım ve onarım çalışmalarının yetersizliği nedeniyle niteliksiz zeminler oluşturmaktadırlar (Şekil 2c). 

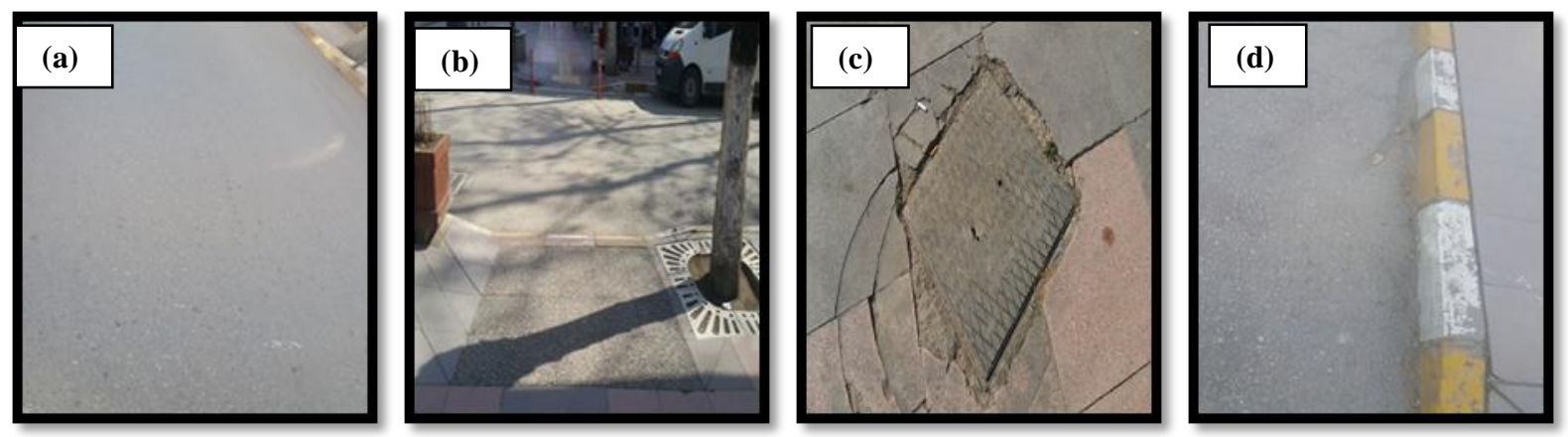

Şekil 2. Alparslan Türkeş Caddesi araç yolu-asfalt (a), yaya geçiti-waschbeton (b), kaldırım-beton plak taş (c) ve bordür-beton $(\mathrm{d})$

$\checkmark$ Necip Fazıl Kısakürek Sokağı üzerinde yer alan zemin kaplamaları: Necip Fazıl Kısakürek Sokağı üzerinde yer alan zemin kaplamaları kapsamında yapılan sınıflamaya göre; araç yollarında asfalt (Şekil 3a), yaya geçitlerinde waschbeton (Şekil 3b), kaldırımlarda beton plak taş (Şekil 3c), bordürlerde ise beton (Şekil 3d) kullanıldığı tespit edilmiştir. Kaldırımlardaki zemin kaplamaları bazı yerlerde kırılıp estetik ve işlevsel özelliğini kaybetmişlerdir (Şekil 3c).
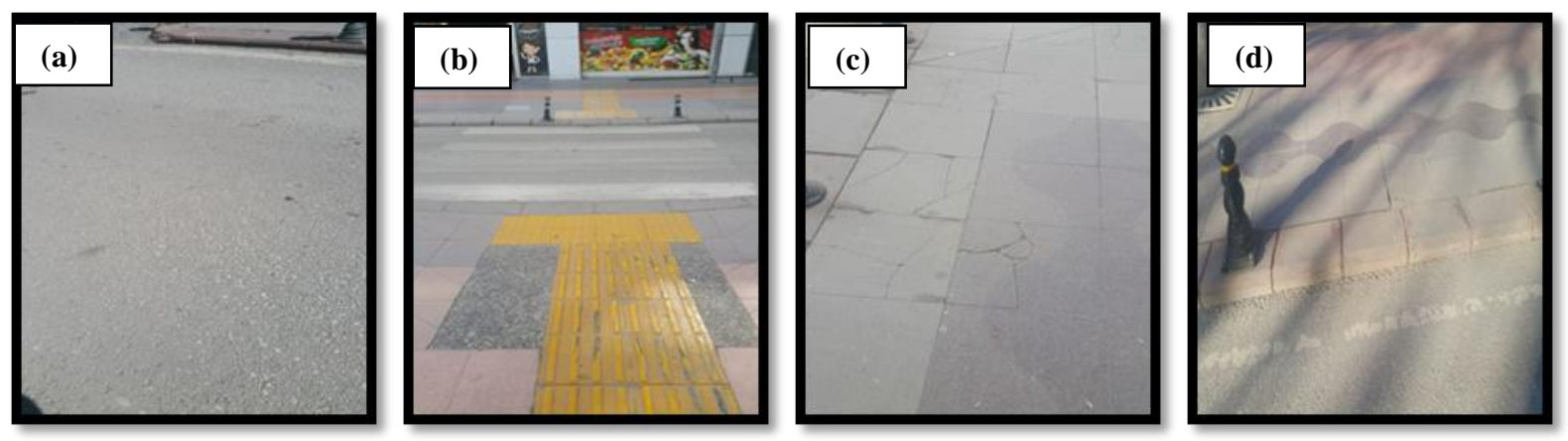

Şekil 3. Necip Fazıl Kısakürek Sokağı araç yolu-asfalt (a), yaya geçiti-waschbeton (b), kaldırım-beton plak taş (c) ve bordür-beton (d)

- Aydınlatma Elemanları: Kentsel mekânın gece kullanımı, algılanması, korunması ve estetiği açısından önemli olan aydınlatma elemanları (Şişman ve Yetim, 2004), sadece 1şı1k verme özelliği ile değerlendirilmemelidir. Dış mekân aydınlatmasında temel amaç, dış mekân elemanlarının işlevi, biçimi ve dokusunu ortaya çıkaran aydınlatmanın yapılmasıdır. Aydınlatma elamanlarının seçimi yapılırken aydınlatma tekniği kadar armatürlerin hava koşullarına göre dayanıklılığı, sağlamlığı ile renk vb. gibi fiziksel özellikleri de dikkate alınmalıdır (Bulut ve ark., 2008).

$\checkmark$ Alpaslan Türkeş Caddesi üzerinde yer alan aydınlatma elemanları: Alparslan Türkeş Caddesi üzerinde yer alan aydınlatma elemanları; tekli (Şekil 4a,b,c,d) ve beşli (Şekil 4e) cadde aydınlatması ile ağaç aydınlatması (Şekil 4f) olarak sınıflandırılmıştır. Araştırma alanında bulunan aydınlatma elemanlarının tamir, boya, bakım ve onarım çalışmaları yetersiz olup, bütünsellik sağlanamamaktadır. Alanın belli bir bölümünde kullanılan ağaç aydınlatmaları ise estetik açıdan güzel bir görünüm sağlamaktadırlar.

$\checkmark$ Necip Fazıl Kısakürek Sokağı üzerinde yer alan aydınlatma elemanları: Necip Fazıl Kısakürek Sokağı üzerinde yer alan aydınlatma elemanları; tekli (Şekil 5a,b) ve ikili (Şekil 5c) sokak aydınlatması ile ağaç aydınlatması (Şekil 5d) olarak sınıflandırılmıştır. Araştırma alanında bulunan aydınlatma elemanları estetik açıdan güzel bir görüntü sağlamakta, ancak gerek birbirleri ile gerekse kent ile bütünlük sağlayamamaktadırlar. Alanda kullanılan ağaç aydınlatmaları ise estetik açıdan güzel bir görünüm sağlamaktadır. 

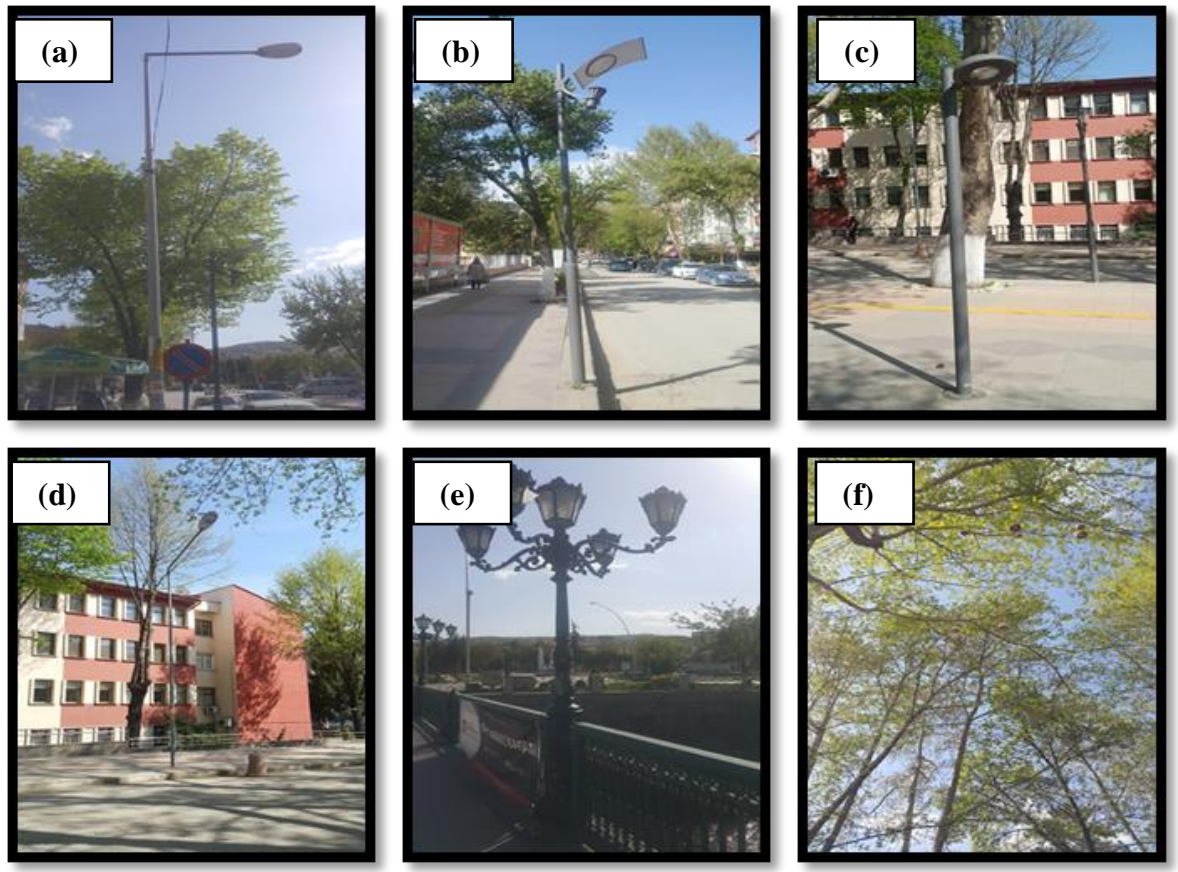

Şekil 4. Alpaslan Türkeş Caddesi üzerinde yer alan tekli (a,b,c,d) ve beşli (e) cadde aydınlatması ile ağaç aydinlatmasi (f)
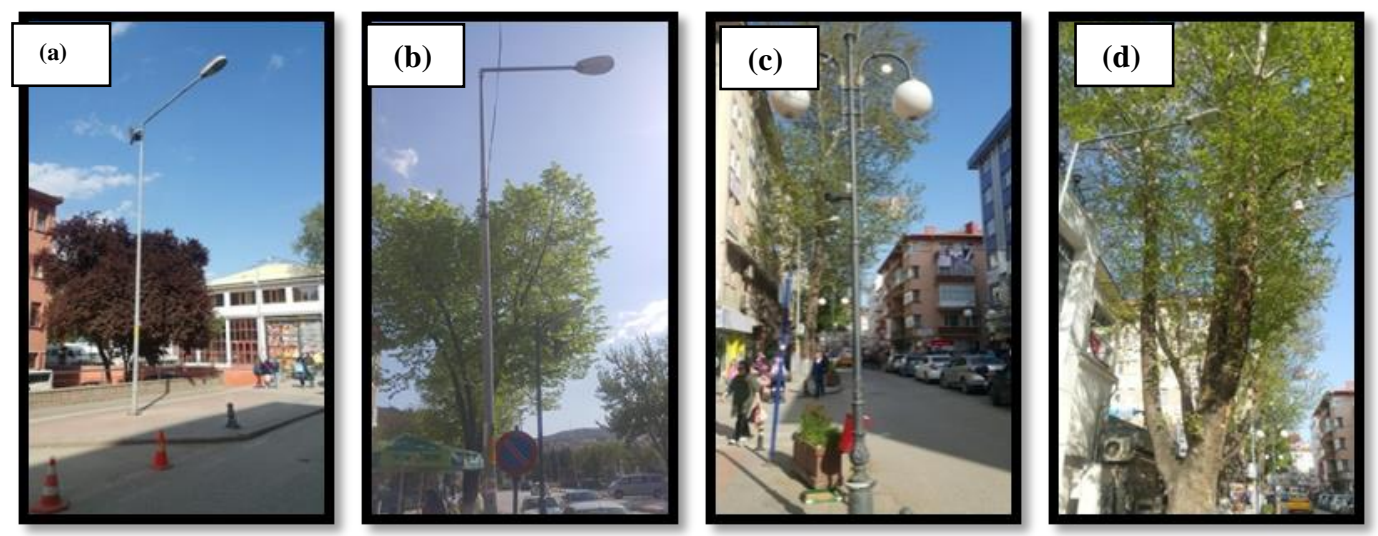

Şekil 5. Necip Fazıl Kısakürek Sokağı üzerinde yer alan tekli (a,b) ve ikili (c) sokak aydınlatması ile ağaç aydinlatması (d)

- İşaret ve Bilgi Levhaları: Yol bulmada, yasaklamalarda ve kontrol sağlamada önemli bilgilerin iletilmesini sağlayan ve kent merkezinde algılanmakta olan görsel kaliteyi de artıran işaret ve bilgi levhaları, kullanım amaçları doğrultusunda tasarlanmalı ve algılanabilir olmalıdırlar (Özsule ve Çağlayan, 2001). Gerek kentteki yabancı kişiler, gerekse kent sakinleri için önem taşıyan ve yön belirten işaret levhaları arasında amaca uygun renk ve form farklılıkları olması gerekmektedir. Bunlar, yeterli uzaklıktan görülebilecek, yaya ve araçlar için tehlikeli konum yaratmayacak şekilde yerleştirilmiş olmalı, yükseklik ve bulundukları yer açısından insan hareketlerini engellememelidirler (Yörük ve ark., 2006).

$\checkmark$ Alpaslan Türkeş Caddesi üzerinde yer alan işaret ve bilgi levhaları: Alparslan Türkeş Caddesi üzerinde yer alan işaret ve bilgi levhaları; yönlendirme levhaları [sokak ve cadde ismi (Şekil 6a), yön levhası/yer belirleyici (Şekil 6b), trafik lambası (Şekil 6c), trafik işareti (Şekil 6d,e,f,g,h,1,i)] ve reklam panoları (Şekil 7) olarak sınıflandırılmıştır. Yönlendirme levhaları ve reklam panoları genel anlamda iyi olup, alanda kısmen boya vs. gibi bakım yapılması gereken panolar da yer almaktadır. 

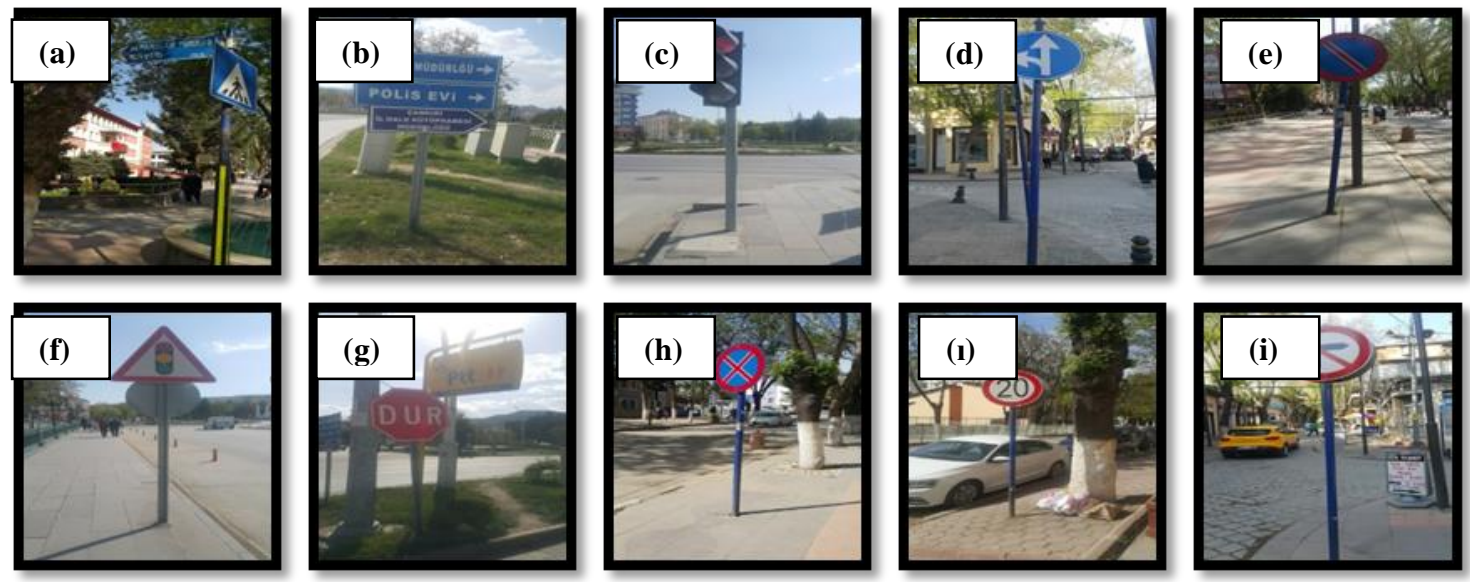

Şekil 6. Alparslan Türkeş Caddesi üzerinde yer alan sokak ve cadde ismi (a), yön levhasi/yer belirleyici (b), trafik lambası (c), trafik işaretleri (d,e,f,g,h,1,i)
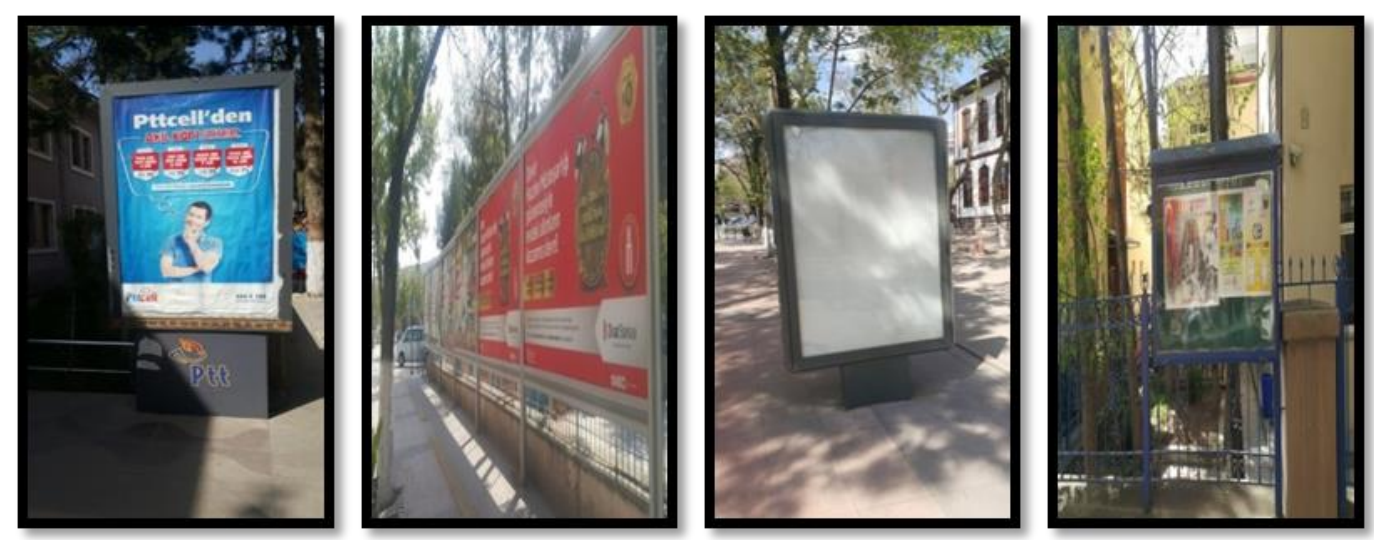

Şekil 7. Alparslan Türkeş Caddesi üzerinde yer alan reklam panoları

$\checkmark$ Necip Fazıl Kısakürek Sokağı üzerinde yer alan işaret ve bilgi levhaları: Necip Fazıl Kısakürek Sokağı üzerinde yer alan işaret ve bilgi levhaları; yönlendirme levhaları [sokak ve cadde ismi, yön levhası/yer belirleyici (Şekil 8a), trafik işaretleri (Şekil 8b,c)] ve reklam panoları (Şekil 9) olarak sınıflandırılmıştır. Yönlendirme levhaları ve reklam panoları genel anlamda iyi durumdadır.
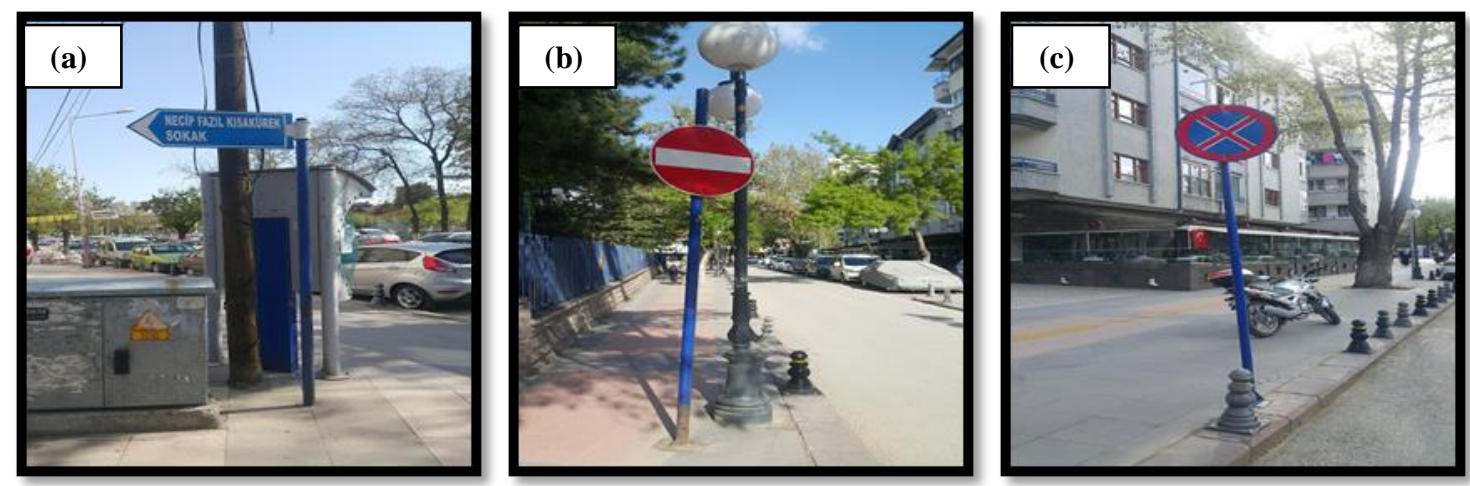

Şekil 8. Necip Fazıl Kısakürek Sokağı üzerinde yer alan sokak ve cadde ismi ile yön levhası/yer belirleyici (a), trafik işaretleri $(b, c)$ 


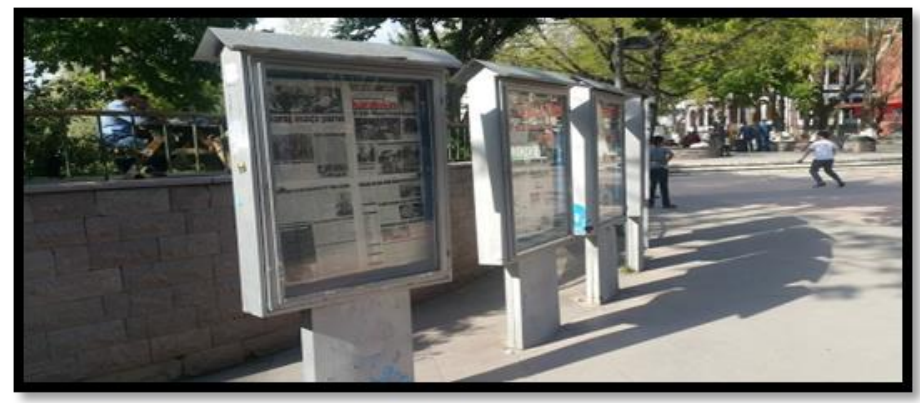

Şekil 9. Necip Fazıl Kısakürek Sokağı üzerinde yer alan reklam panoları

- Sınır Elemanları: Dış mekânda insan trafiğinden çok, araç trafiğinin görsel engel oluşturmadan kontrol altında tutulmasını sağlayan düzenleme elemanları (Şişman ve Yetim, 2004) olan sınır elemanları, fiziksel geçişin kontrol altında tutulmasını sağlayan elemanlar olduğu için görsel engel oluşturmamalıdırlar.

$\checkmark$ Alpaslan Türkeş Caddesi üzerinde yer alan sınır elemanları: Alpaslan Türkeş Caddesi üzerinde araç geçişini engellemek amacıyla farklı tiplerde bariyerler (Şekil 10) kullanılmıştır. Bu bariyerler gerek birbirleri gerekse çevrelerinde yer alan diğer kentsel donatı elemanları ile bütünlük sağlayamadığı için görsel ve fiziksel karmaşaya neden olmaktadır.
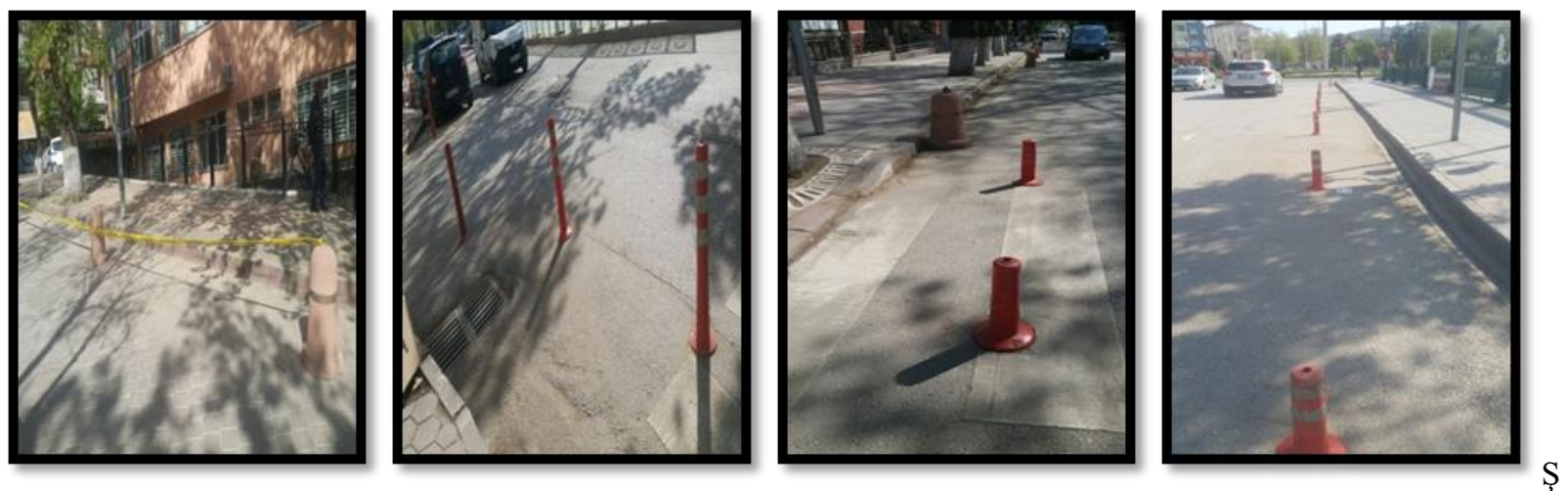

ekil 10. Alparslan Türkeş Caddesi üzerinde yer alan bariyerler

Necip Fazıl Kısakürek Sokağı üzerinde yer alan sınır elemanları: Necip Fazıl Kısakürek Sokağı üzerinde sınır elemanı olarak kullanılan bariyerlerin bir bölümünün birbiri ve alan ile uyumu bulunmamakta, yanı sıra bakım ve onarım gerektirmektedirler (Şekil 11a). Alanda sınır elemanı olarak kullanılan bitki kasaları (Şekil $11 b)$ ise estetik ve işlevsel yönden olumludurlar.
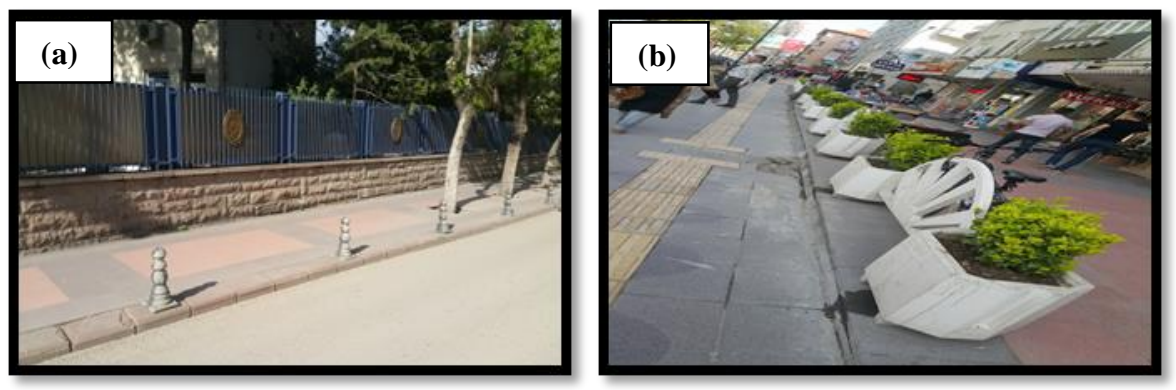

Şekil 11. Necip Fazıl Kısakürek Sokağı üzerinde yer alan sınır elemanları (a) ve bitki kasaları (b)

- Su Elemanları: İnsanlar üzerinde görsel ve psikolojik etki yaratan su elemanları, kullanıldıkları mekâna hareket, canlılık ve estetik görünüm kazandırmaktadırlar.

$\checkmark$ Alparslan Türkeş Caddesi üzerinde yer alan su elemanları: Alparslan Türkeş Caddesi üzerinde su elemanı bulunmamaktadır.

$\checkmark$ Necip Fazıl Kısakürek Sokağı üzerinde yer alan su elemanları: Necip Fazıl Kısakürek Sokağı üzerinde 2 adet dikdörtgen formlu (Şekil 12a) ve 2 adeti sokağın Alparslan Türkeş Caddesi ile birleşen kısımda (Şekil 
12b), 2 adeti ise sokağın Elif Caddesi ile birleşen kısımda (Şekil 12c) konumlandırılmış toplamda 4 adet dairesel formlu olmak üzere iki tip havuz yer almaktadır. Havuzların formları, yapım malzemeleri ve işlevsel olmamaları görsel açıdan olumsuz etkiye neden olmaktadır.
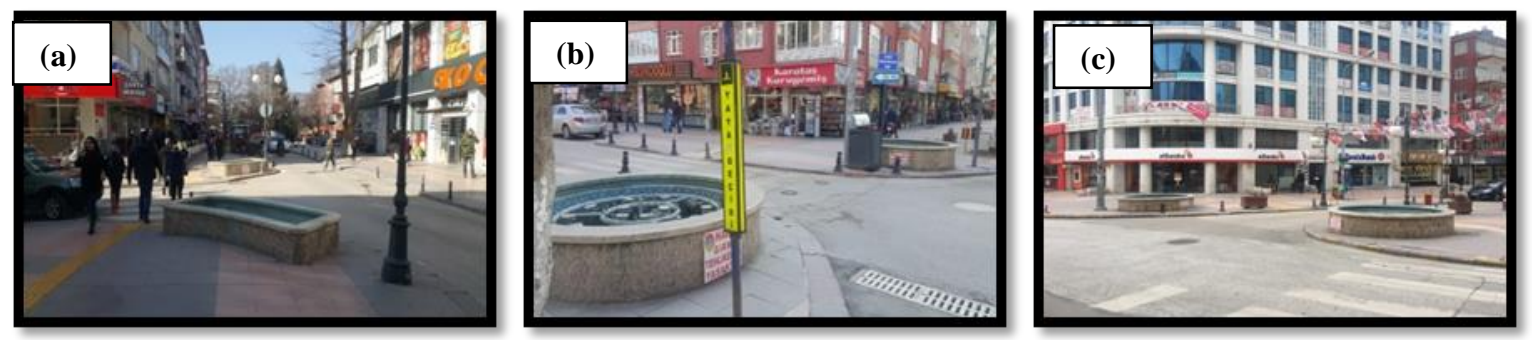

Şekil 12. Necip Fazıl Kısakürek Sokağı üzerinde yer alan dikdörtgen (a) ve dairesel $(b, c)$ havuzlar

- Satı̧̧ Birimleri: Kent halkının ihtiyaçlarını karşılamak amacıyla kullanılan büfelerin kent görünümüyle uyum sağlaması gerekmektedir.

$\checkmark$ Alparslan Türkeş Caddesi üzerinde yer alan satış birimleri: Alparslan Türkeş Caddesi üzerinde büfe bulunmamaktadır.

$\checkmark$ Necip Fazıl Kısakürek Sokağı üzerinde yer alan satış birimleri: Necip Fazıl Kısakürek Sokağı üzerinde 1 adet büfe bulunmaktadır (Şekil 13).

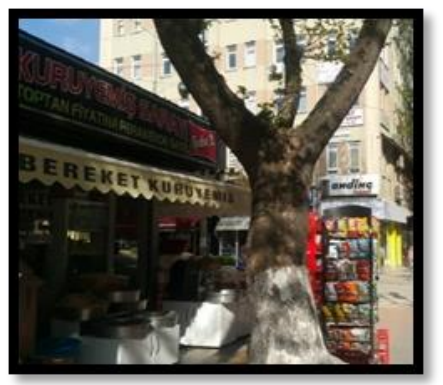

Şekil 13. Necip Fazıl Kısakürek Sokağı üzerinde yer alan büfe

- Çöp Kutuları: Kamusal dış mekânlarda bulunan çöp kutuları diğer peyzaj elemanları ile fonksiyonel uyum içinde bulunmalıdırlar. Çöp kutusu, çöpü muhafaza etmenin yanı sıra onu iyi bir şekilde gizleyebilmelidir (Yörük ve ark., 2006). Estetik ve sağlı açısından olumsuz etkileri nedeni ile çöplerin kent ortamından hemen uzaklaştırılması gerekmektedir. Çöp kutuları dayanıklı ve çevresine koku, sıvı vb. gibi atıkların yayılmasını önleyici nitelikte olmalıdırlar.

$\checkmark$ Alparslan Türkeş Caddesi üzerinde yer alan çöp kutuları: Alparslan Türkeş Caddesi üzerinde yer alan çöp kutuları farklı tiplerde olup kapaksız olarak tasarlanmışlardır (Şekil 14). Dolayısıyla etrafa yayılabilecek koku ve sıvı atıkları önleyici nitelikte değildirler.
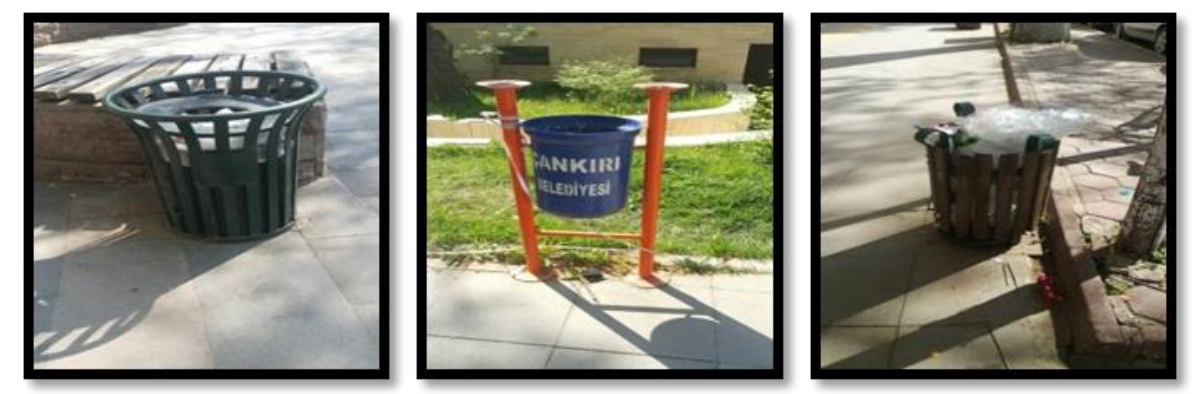

Şekil 14. Alparslan Türkeş Caddesi üzerinde yer alan çöp kutuları

Necip Fazıl Kısakürek Sokağı üzerinde yer alan çöp kutuları: Necip Fazıl Kısakürek Sokağı üzerinde yer alan çöp kutuları (Şekil 15a) etrafa yayılabilecek koku ve sıvı atıkları önleyici nitelikte değildirler. Sokak 
üzerinde gelişi güzel konumlandırılmış çöp konteyneri (Şekil 15b) ise bakımsızlık nedeniyle insan sağlığını tehdit eder hale gelmiş olup görsel kirliliğe neden olmaktadır.
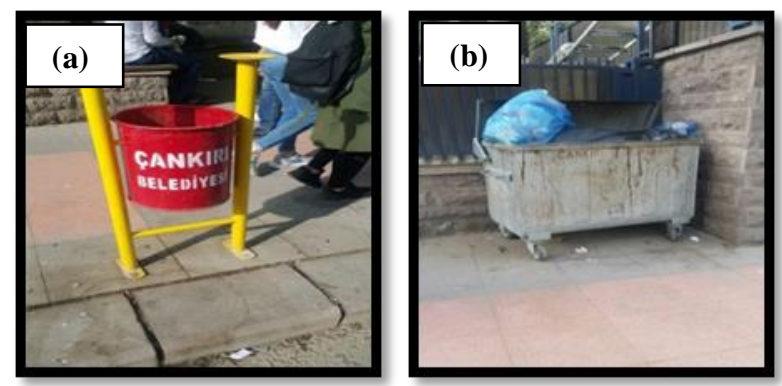

Şekil 15. Necip Fazıl Kısakürek Sokağı üzerinde yer alan kapaksız çöp kutusu (a) ve çöp konteyneri (b)

- İletişim İşlevine Yönelik Elemanlar: Kolay ulaşılabilen noktalarda konumlandırılmaları gereken iletişim işlevine yönelik elemanların bakım ve onarım çalışmalarının yapılması, estetik açıldan ise diğer donatı elemanları ile uyumlu olup kent dokusu ile bütünlük sağlamaları gerekmektedir.

$\checkmark$ Alpaslan Türkeş Caddesi üzerinde yer alan iletişim işlevine yönelik elemanlar: Alpaslan Türkeş Caddesi üzerinde yer alan ve kent halkının iletişim sağlamak amacıyla kullandıkları donatı elemanları; telefon kulübesi (Şekil 16a) ve bankamatikler (ATM) (Şekil 16b,c,d) olmak üzere sınıflandırılmıştır. Her iki donatı elemanı da yaya hareketliliğini ve akıcılığını engellemeyecek şekilde yerleştirilmişlerdir.
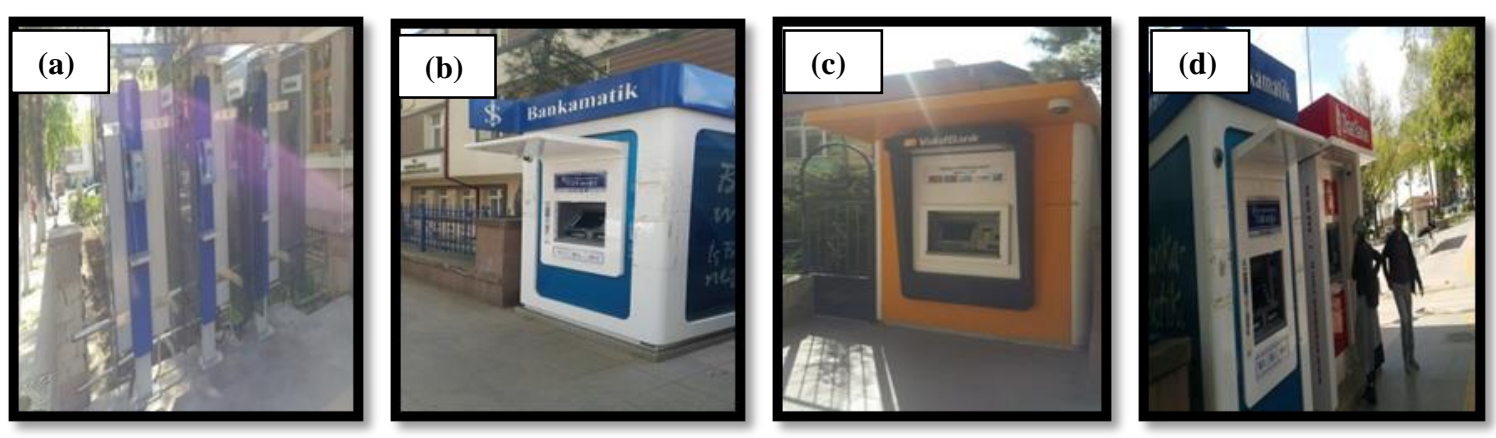

Şekil 16. Alparslan Türkeş Caddesi üzerinde yer alan telefon kulübesi (a) ve bankamatikler (b,c,d)

Necip Fazıl Kısakürek Sokağı üzerinde yer alan iletişim işlevine yönelik elemanlar: Necip Fazıl Kısakürek Sokağı üzerinde 1 adet bankamatik (Şekil 17) bulunmakta olup, yaya hareketliliğini ve akıcılığını engellemeyecek şekilde yerleştirilmiştir.

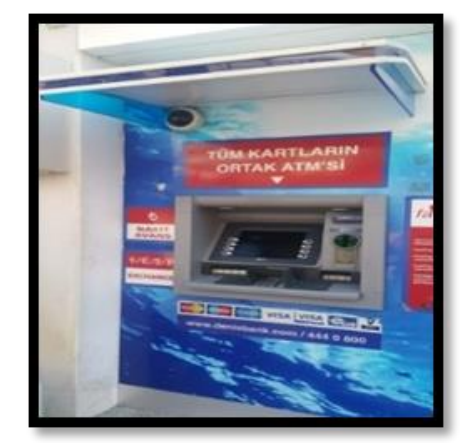

Şekil 17. Necip Fazıl Kısakürek Sokağı üzerinde yer alan bankamatik

- Alt Yapı Tesisleri Bakım Kapakları: Ulaşımı engellememek amacıyla yol seviyesi ile aynı düzeyde olmalı, bakım ve onarım çalışmaları yapılarak kent insanı için oluşabilecek tehlike engellenmelidir.

$\checkmark$ Alpaslan Türkeş Caddesi üzerinde yer alan alt yapı tesisleri bakım kapakları: Alparslan Türkeş Caddesi üzerinde yer alan alt yapı tesisleri bakım kapakları (telefon, kanalizasyon vb. gibi) yol seviyesi ile aynı düzeyde olmamaları ve bakımsızlık nedeni ile ulaşımı engellemekte ve görsel kirliliğe neden olmaktadırlar (Şekil 18). 

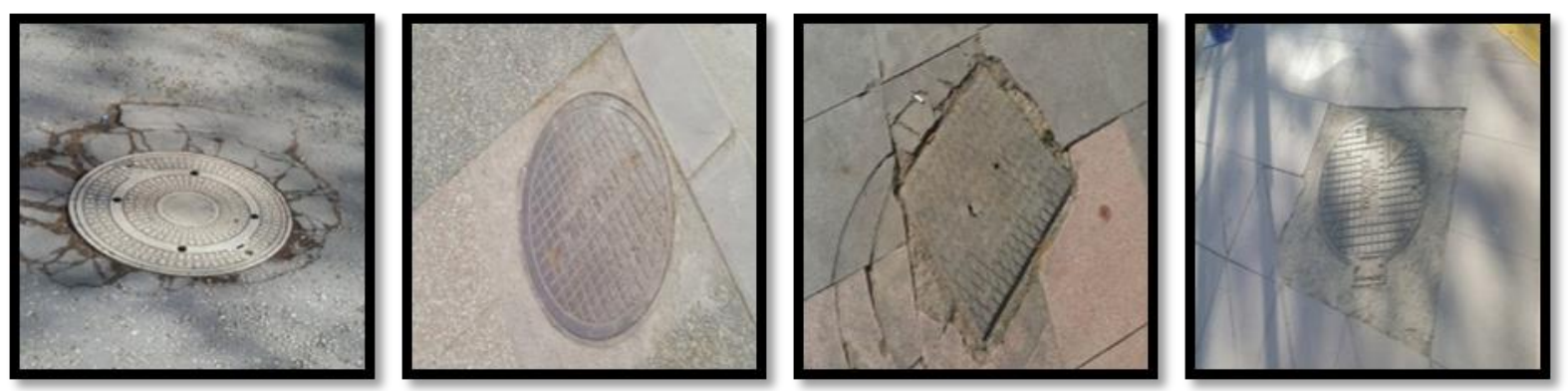

Şekil 18. Alparslan Türkeş Caddesi üzerinde yer alan alt yapı tesisleri bakım kapakları

Necip Fazıl Kısakürek Sokağı üzerinde yer alan alt yapı tesisleri bakım kapakları: Necip Fazıl Kısakürek Sokağı üzerinde yer alan alt yapı tesisleri bakım kapakları (telefon, kanalizasyon vb. gibi) yol seviyesi ile aynı düzeyde olmamaları ve bakımsızlık nedeni ile ulaşımı engellemekte ve görsel kirliliğe neden olmaktadırlar (Şekil 19).
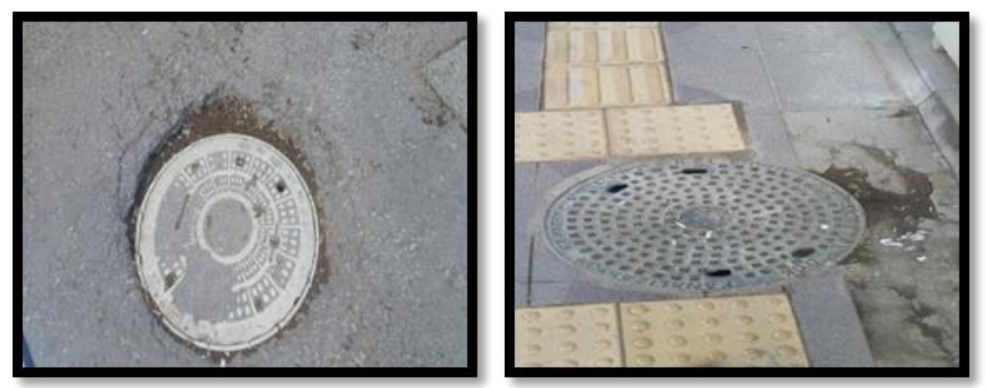

Şekil 19. Necip Fazıl Kısakürek Sokağı üzerinde yer alan alt yapı tesisleri bakım kapakları

- Yol Izgaraları: Yağmur ve atık suyunun yer altına geçmesini sağlayan donatı elemanları olup, tehlike oluşturmaması için yol seviyesinde olmalıdırlar.

$\checkmark$ Alpaslan Türkeş Caddesi üzerinde yer alan yol ızgaraları: Alparslan Türkeş Caddesi üzerinde yer alan metal ızgaraların büyük bir bölümü yol seviyesi ile aynı düzeyde olmamaları ve bakımsızlık nedeni ile ulaşımı engellemekte ve görsel kirliliğe neden olmaktadırlar (Şekil 20).
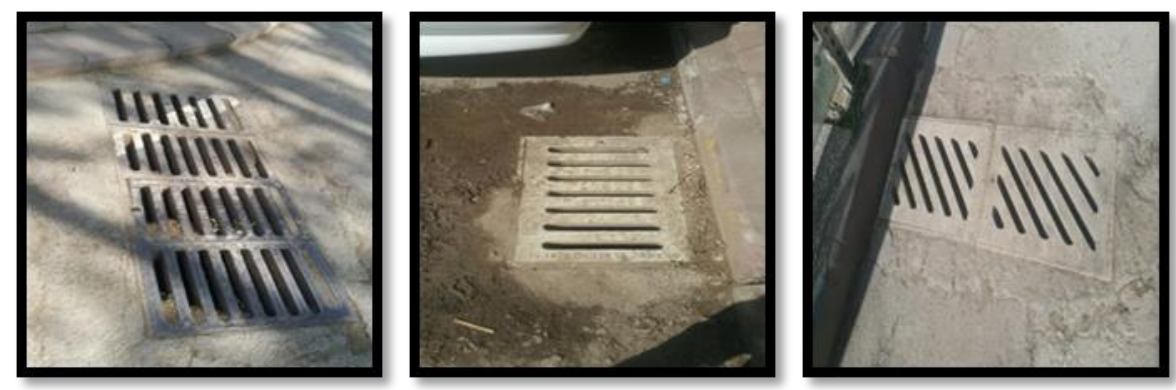

Şekil 20. Alparslan Türkeş Caddesi üzerinde yer alan yol ızgaraları

Necip Fazıl Kısakürek Sokağı üzerinde yer alan yol ıggaraları: Necip Fazıl Kısakürek Sokağı üzerinde yer alan metal ızgaraların büyük bir bölümü yol seviyesi ile aynı düzeyde olmamaları ve bakımsızlık nedeni ile ulaşımı engellemekte ve görsel kirliliğe neden olmaktadırlar (Şekil 21). 


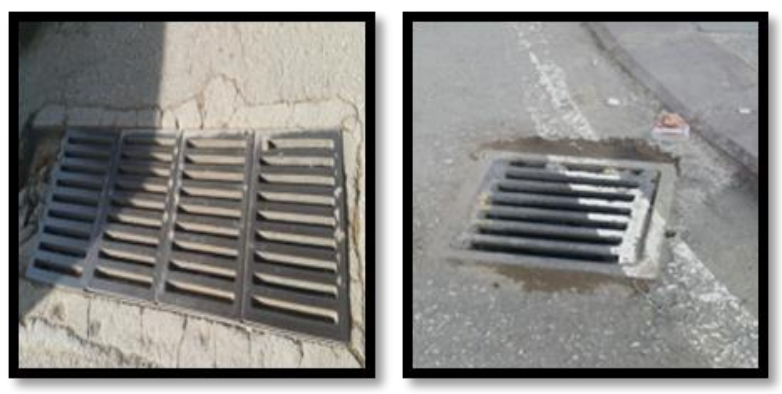

Şekil 21. Necip Fazıl Kısakürek Sokağı üzerinde yer alan yol ızgaraları

- Trafolar: Tehlike oluşturmayacak şekilde konumlandırılmalı, bakım ve onarım çalışmaları yapılmalıdır. Kent merkezinde algılanmakta olan görsel kaliteyi etkiledikleri için estetik olması ve kent görünümüyle uyum sağlamalarına dikkat edilmelidir.

$\checkmark$ Alpaslan Türkeş Caddesi üzerinde yer alan trafolar: Alparslan Türkeş Caddesi üzerinde bulunan trafoların bakım ve onarım çalışmaları (boya, tamir vs.) yetersizdir (Şekil 22).
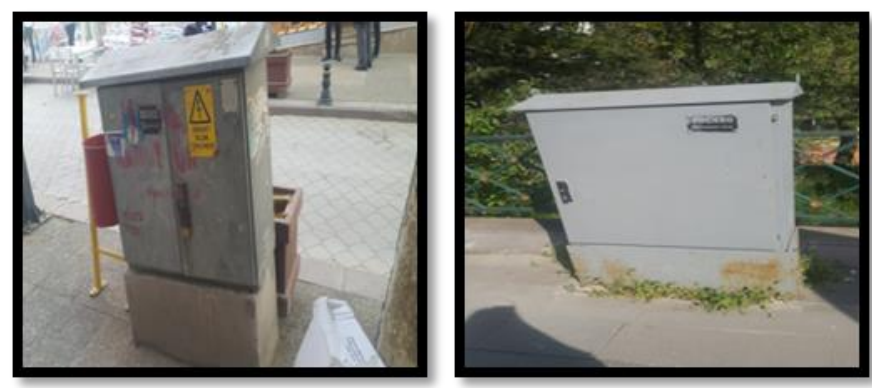

Şekil 22. Alparslan Türkeş Caddesi üzerinde yer alan trafolar

Necip Fazıl Kısakürek Sokağı üzerinde yer alan trafolar: Necip Fazıl Kısakürek Sokağı üzerinde bulunan trafonun bakım ve onarım çalışmaları (boya, tamir vs.) yetersizdir (Şekil 23).

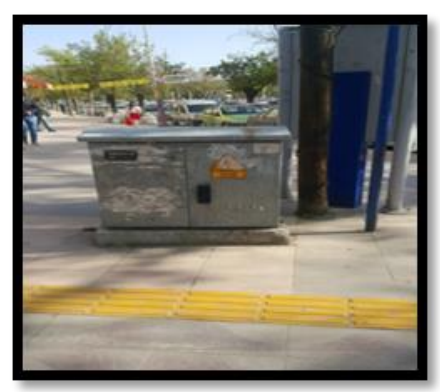

Şekil 23. Necip Fazıl Kısakürek Sokağı üzerinde yer alan trafo

- Bitkisel Elemanlar: Estetik ve işlevsel amaçlı kullanılan bitkisel elemanlar, konumlandırıldıkları mekâna estetik özellik katmakta, yönlendirme, istenilen noktaların vurgulanması, olumsuz görünümlerin önlenmesi ve sınırlama vb. gibi işlevsel özellik göstermekte ve kent ekosistemi için büyük önem taşımaktadırlar.

$\checkmark$ Alpaslan Türkeş Caddesi üzerinde yer alan bitkisel elemanlar: Alparslan Türkeş Caddesi üzerinde yer alan bitkisel elemanlar; bitki kasaları içinde bitki kullanımı (Şekil 24a,b) ve yol ağaçlandırmaları (Şekil 24c) olarak sınıflandırılmıştır. Bitkisel elemanlar genel olarak iyi durumdadırlar. 

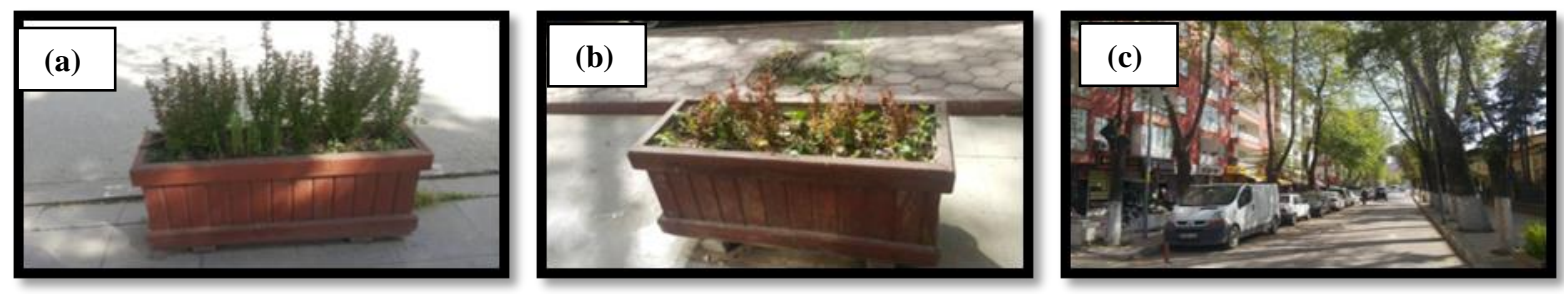

Şekil 24. Alparslan Türkeş Caddesi üzerinde yer alan bitki kasaları (a,b) ve yol ağaçlandırması (c)

$\checkmark$ Necip Fazıl Kısakürek Sokağı üzerinde yer alan bitkisel elemanlar: Necip Fazıl Kısakürek Sokağı üzerinde yer alan bitkisel elemanlar; bitki kasaları içinde bitki kullanımı (Şekil 25a,b,c) ve yol ağaçlandırmaları (Şekil 25d) olarak sınıflandırılmıştır. Bitki kasaları hizmet veren iş yerleri için sınırlayıcı eleman (Şekil 25b) olarak da kullanılmıştır. Yol ağaçlandırmaları genel olarak iyi durumda olup bazı kısımlarda bakım ve tamamlama çalışmalarının yetersiz olması nedeniyle işlevsel ve estetik açıdan olumsuz etkiye sahip bitki türleri bulunmaktadır.
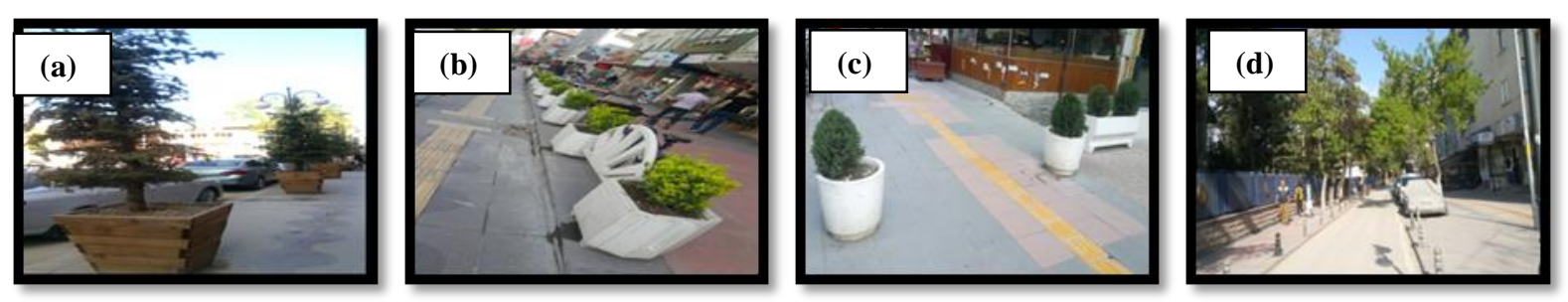

Şekil 25. Necip Fazıl Kısakürek Sokağı üzerinde yer alan bitki kasaları (a,b,c) ve yol ağaçlandırmaları (d)

\section{Sonuç ve Öneriler}

Çankırı kenti Alparslan Türkeş Caddesi ve Necip Fazıl Kısakürek Sokağı üzerinde bulunan kentsel donatı elemanlarının sınıflandırılması ve peyzaj mimarlığı açısından değerlendirilmesi amacıyla yapılan bu araştırmanın sonucu genel olarak değerlendirildiğinde; mevcut kentsel donatı elemanlarının belirli bir bölümünün bakım ve onarım çalışmalarının yapılmaması sonucunda estetik açıdan görsel kirliliğe yol açtıkları saptanmıştır. Ayrıca her bir kentsel donatı elemanının farklı kurumların denetiminde olması nedeni ile uyum anlamında kent ile bütünlük sağlamadıkları saptanmıştır. Alparslan Türkeş Caddesi ve Necip Fazıl Kısakürek Sokağı üzerinde bulunan kentsel donatı elemanları özelinde yapılan değerlendirme için ise:

- Zemin kaplamları: Her iki araştırma alanında yer alan kaldırımlarda, özellikle altyapı tesisleri bakım kapaklarının bulunduğu yerlerdeki zemin kaplamalarının hasar gördüğü, araç yolları ve bordürlerin genel olarak iyi durumda olduğu, engelli bireyler için kullanılan sarı çizgilerin ise bazı noktalarda hasar gördüğü tespit edilmiştir. Zarar görmüş olan tüm zemin kaplamalarına bakım ve onarım çalışmalarının yapılması, bakım ve onarım çalışmalarında ise zeminin çok iyi tesviye edilmesi ve uygun stabilize malzeme ile kaplanması gerekmektedir.

- Aydınlatma elemanları: Alparslan Türkeş Caddesinin belirli kısmında yer alan ve işlevsel/estetik açıdan olumsuz etki yaratan tahrip olmuş aydınlatma elemanlarının bakım ve onarım çalışmalarının yapılması gerekmektedir. Necip Fazıl Kısakürek Sokağındaki aydınlatma elemanları genel olarak iyi durumdadır, ancak gerek birbirleri ile gerekse kent ile bütünlük sağlayamamaktadırlar. Her iki araştırma alanlarına amaca yönelik tasarım ilkeleri göz önünde bulundurularak dekoratif aydınlatma elemanları yerleştirilerek, bütünsellik korunmalıdır. Aydınlatma elemanları sadece 1 şı verme amacı ile değil estetik açıdan da değerlendirilmelidirler.

- İşaret ve bilgi levhaları: Her iki araştırma alanlarında yer alan işaret ve bilgi levhalarının genel anlamda iyi olduğu, ancak kullanım amaçlarına göre belirli bir standarda kavuşturulması, renk ve model seçiminde işlevsel ve estetik görünümlerin göz önünde bulundurulması, yanı sıra özellikle Alparslan Türkeş Caddesinde yer alan işaret ve bilgi levhalarının boya vs. ile bakım ve onarımlarının yapılarak çevreye ve birbirine uyumlu hale getirilmeleri gerekmektedir.

- Sinır elemanları: Her iki araştırma alanında da farklı tiplerde yerleştirilen bariyerler görsel karmaşaya neden olduğu için belli bir standarda kavuşturulmalıdırlar. Yeni yerleştirilecek sınır elemanları hem araç-yaya yolunu ayırmak hem de kargaşanın engellenmesi amacıyla uygun yerlere konumlandırılmalı, renk ve model seçiminde işlevsel uygunluk ve estetik değerler göz önünde bulundurulmalı, göz seviyesinin altında tasarlanıp uygulanmalı ve güvenli olmalarına özen gösterilmelidir. 
- Su elemanları: Necip Fazıl Kısakürek Sokağı üzerinde yer alan havuzların formları, yapım malzemeleri ve işlevsel olmamaları görsel açıdan olumsuz etkiye neden olmakta, havuzların işlevsiz olmaları aynı zamanda tehlike oluşturmaktadır. Dolayısıyla araştırma alanında yer alan bu havuzların bakım ve onarım çalışmalarının yapılarak işlev kazandırılmaları gerekmektedir.

- Satış birimleri: Necip Fazıl Kısakürek Sokağı üzerinde yer alan büfenin kent görünümüyle uyumu sağlanmalıdır.

- Çöp kutuları: Her iki araştırma alanının uygun ve gerekli kısımlarına; yeterli sayıda, etrafa yayılabilecek koku ve sıvı atıklarını önleyici nitelikte ve gerek birbirleri gerekse diğer donatı elemanları ile uyum sağlayacak özellikte tasarlanmış çöp kutularının/konteynerlerinin yerleştirilmesi gerekmektedir.

- İletişim işlevine yönelik elemanlar: Her iki araştırma alanlarında yer alan iletişim işlevine yönelik kullanılan elemanlar yaya hareketliliğini ve akıcıllı̆ı engellemeyecek şekilde yerleştirilmişlerdir. Ancak bankamatiklerin ait oldukları banka için sabit reklam imkânı yaratmaları, ürün tasarımında çeşitliliğe neden olmaktadır.

- Alt yapı tesisleri bakım kapakları: Her iki araştırma alanlarında yer alan alt yapı tesisleri bakım kapaklarının (telefon, kanalizasyon vb. gibi) ulaşımı engellememesi amacıyla yol seviyesi ile aynı düzeyde yerleştirilmesi, bakım ve onarım çalışmalarının yapılması gerekmektedir.

- Yol ızgaraları: Her iki araştırma alanlarında yer alan ve yağmur suyu ile atık suların yer altına geçmesini sağlayan yol ızgaralarının güvenli/pürüzsüz zeminler oluşturmaları için yol seviyesinde olmalarına özen gösterilmesi, bakım ve onarım çalışmalarının yapılması gerekmektedir.

- Trafolar: Her iki araştırma alanlarında yer alan trafoların kent ile uyumunun sağlanması, yaya hareketliliği ve akıcılığını engellemeyecek şekilde konumlandırılmaları ve kent halkının güvenliği açısından bakımlarının periyodik olarak yapılması gerekmektedir.

- Bitkisel elemanlar: Alparslan Türkeş Caddesindeki bitkilendirme genel olarak iyi durumdadır. Necip Fazıl Kısakürek sokağında ise yol ağaçlandırmaları genel olarak iyi durumda olup bazı kısımlarda bakım ve tamamlama çalışmalarının yetersiz olması nedeniyle işlevsel ve estetik açıdan olumsuz etkiye sahip bitki türleri bulunmaktadır. İyi durumda olan bitki türlerinin korunup işlevsel ve estetik açıdan olumsuz etkiye sahip olan bitki türlerinin ise yol ağaçlandırmalarında kullanılan bitki türleri ile tamamlanması gerekmektedir.

Sonuç olarak araştırma alanlarında bulunan kentsel donatı elemanlarının tasarımından kent mekânlarına yerleştirilmesi, bakım ve onarım çalışmalarının yapılmasına kadar tüm aşamalarında, kent sağlığı, görsel estetik ve işlevsellik dikkate alınmalı, yerel yönetimler, ilgili kamu kurum ve kuruluşlarının yanı sıra ilgili meslek disiplinlerinin koordineli çalışmaları sağlanmalıdır. Kentsel donatı elemanlarının kullanımında dikkati çeken hataların tekrarlanmaması için, kullanıldıkları alanların bütünlüğü göz önüne alınıp, açık ve kapalı alan düzenlemelerinde birlikteliğin sağlanması ve kente özgü tasarımların yapılması gerekmektedir.

\section{Kaynaklar}

1. Asatekin M (2001). Kentin Kurumsal Kimliği ve Kentin Donatımında Eşgüdüm, I. Uluslararası Kent Mobilyaları Sempozyumu Bildiriler Kitabı, 9-11 Mayıs, 57-61.

2. Aydoğdu H (2017). Kentsel Donatı Elemanlarının Peyzaj Mimarlığında Kullanımı. Lisans Bitirme Tezi (yayınlanmamış), Selçuk Üniversitesi, Ziraat Fakültesi, Peyzaj Mimarlığı Anabilim Dalı, Konya.

3. Başal M, Memlük Y, Yılmaz O (1993). Peyzaj Konstrüksiyonu. Ankara Üniversitesi Ziraat Fakültesi Yayınları: 1322, Ders Kitabı: 381, Ankara, 170s.

4. Başal M, Memlük Y, Yılmaz O, Kurum E (1997). Peyzaj Konstrüksiyonu. Ankara Üniversitesi Ziraat Fakültesi Yayınları: 1484, Ders Kitabı:445, Ankara, 186s.

5. Bayraktar N, Tekel A, Ercoșkun Ö (2008). Ankara Atatürk Bulvarı Üzerinde Yer Alan Kentsel Donatı Elemanlarının Sınıflandırılması, Değerlendirilmesi ve Kent Kimliği İlişkisi. Gazi Üniversitesi Mühendislik Mimarlık Fakültesi Dergisi, 23(1): 105-118.

6. Bulut Y, Atabeyoğlu Ö, Yeşil P (2008). Erzurum Kent Merkezi Donatı Elemanlarının Ergonomik Özelliklerinin Değerlendirilmesi Üzerine Bir Araştırma. Ankara Üniversitesi Ziraat Fakültesi Tarım Bilimleri Dergisi, 14(2): 131-138.

7. Güney A, Erdem Ü, Zafer B, Hepcan Ş (1996). Peyzaj Konstrüksiyonu (Donatı Elemanları). Ege Üniversitesi Ziraat Fakültesi Yayınları No:514, Peyzaj Mimarlığı Bölümü Ders Kitabı, İzmir, 149 s.

8. Güzel AG, Sözen MF (2003). Tarih-Kent ve Estetik Bağlamında Kent Mobilyaları: Antalya, Kaleiçi Örneği, II. Uluslararası Kent Mobilyaları Sempozyumu\&Fuarı Bildiriler Kitabı, 24-27 Nisan, 159-169.

9. Kuter N (2007). Çankırı Kenti Açık ve Yeşil Alan Varlı̆̆ı İçinde Tarihi Kent Merkezinin Kentsel Peyzaj Tasarımı Açısından Değerlendirilmesi. Doktora Tezi (yayınlanmamış), Ankara Üniversitesi, Fen Bilimleri Enstitüsü, Peyzaj Mimarlığı Anabilim Dalı, Ankara. 
10. Kuter N, Erdoğan E (2009). Kentsel Donatı Elemanlarının Peyzaj Mimarlı̆̆ı Açısından Değerlendirilmesi. Çankırı Araştırmaları Dergisi, 243-256.

11. Öner Bilen S (2004). Kentsel Dış Mekanların Tasarımında Antropometrik Verilere Bağlı Olarak Peyzaj Elemanlarının Ankara Örneğinde Araştırılması. Doktora Tezi (yayınlanmamış), Ankara Üniversitesi, Fen Bilimleri Enstitüsü, Peyzaj Mimarlığı Anabilim Dalı, Ankara.

12. Özgeriş M (2018). Kentsel Donatı Elemanlarının Kent Dokusu Yönünden Değerlendirilmesi: Erzurum İli Örneği. Afyon Kocatepe Üniversitesi Mühendislik ve Fen Bilimleri Dergisi, 18(2): 561-574.

13. Özsule Z, Çağlayan AY (2001). Kent Tasarımında İşaret Levhalarının Kullanımının İstanbul İli Tarihi Yarımada Örneğinde İrdelenmesi, I. Uluslararası Kent Mobilyaları Sempozyumu Bildiriler Kitabı, 9-11 May1s, 381-389.

14. Sağlık A, Sağlık E, Kelkit A (2014). Kentsel Donatı Elemanlarının Peyzaj Mimarlığı Açısından İrdelenmesi: Çanakkale Kent Merkezi Örneği, 1. Uluslararası Kentsel Planlama-Mimarlık-Tasarım Kongresi, 8-11 Mayıs, Kocaeli/Türkiye, pp.1023-1035.

15. Siu KWM (2005). Pleasurable Products: Public Space Furniture with Userfitness. Journal of Engineering Desing, 16(6): 545-555.

16. Şişman EE, Yetim L (2004). Tekirdağ Kentinde Donatı Elemanlarının Peyzaj Mimarlığı Açısından İrdelenmesi. Trakya Üniversitesi Fen Bilimleri Dergisi, 5(1): 43-51.

17. Taylor N (1999). The Elements of Townscapeand the Art of Urban Desin. Journal of Urban Desing, 4(2): 195-209.

18. Yörük İ, Gülgün B, Sayman M, Ünal Akkaya F (2006). Peyzaj Planlama Çalışmaları Kapsamında Ege Üniversitesi Kampüs Örneğindeki Peyzaj Donatı Elemanlarının Ergonomik-Antropometrik Açıdan İrdelenmesi. Ege Üniversitesi Ziraat Fakültesi Dergisi, 43(1): 157-168. 